Historic, archived document

Do not assume content reflects current scientific knowledge, policies, or practices. 



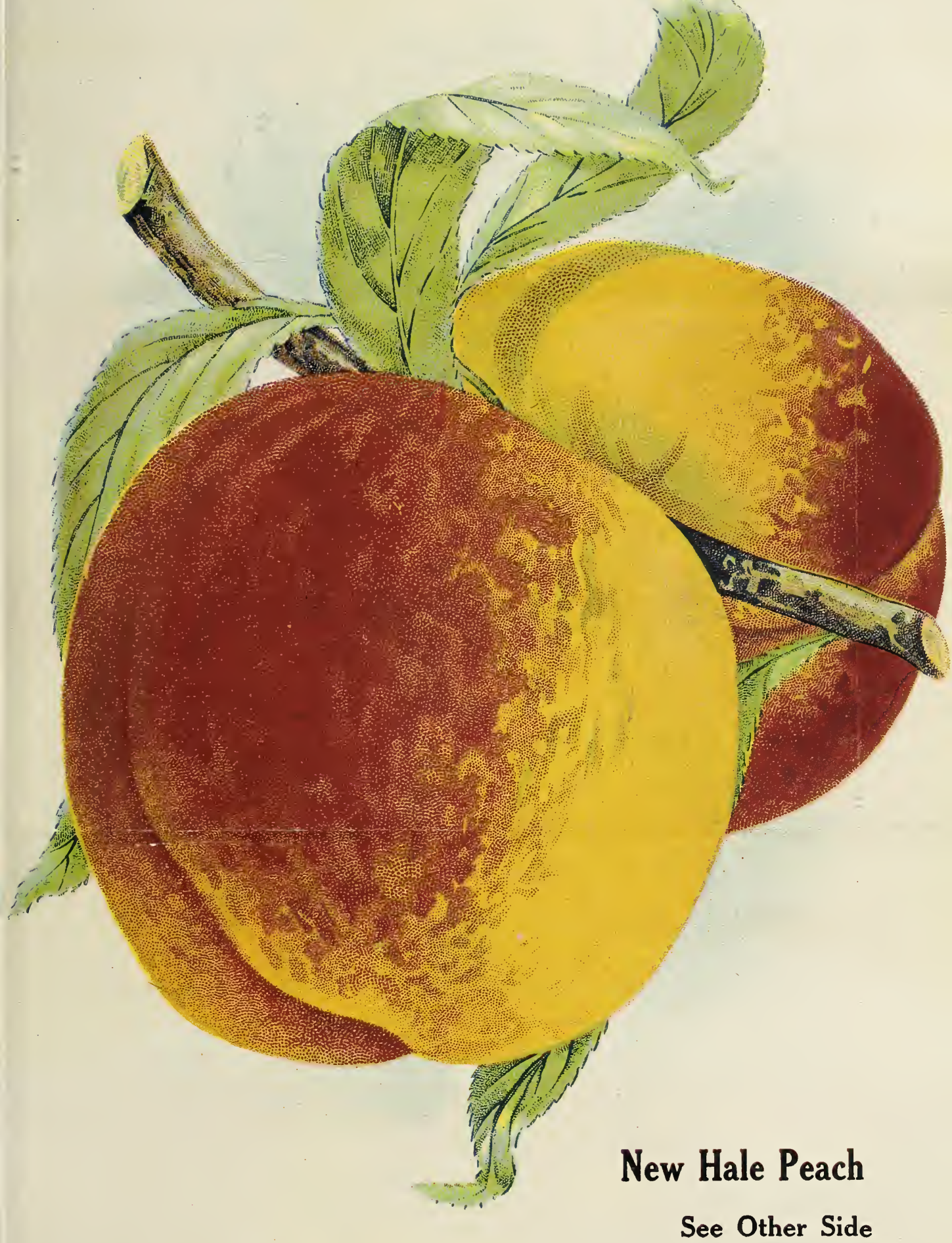




\section{NEW HALE PEACH}

This variety has been fruited here, and it has attracted the attention of all growers who have seen the wonderful fruit.

The peach is of immense size, fully one= half larger than Elberta Deep golden yellow with most attractive carmine-blush. Skin thick; smooth and velvety, without fuzz. Flesh deep yellow, very solid, fine grained, melting and luscious. It beats the Crawford for flavor. Perfect freestone. Wonderful keeper and shipper, always as solid as an apple, and firm enough to ship in barrels. Tree thrifty grower, hardier than Elberta, and wonderfully productive. Ripens five to seven days earlier than Elberta.

\section{Supply Limited, Order Early}

Price, First Class, XXX Grade -5 to 6 feet, $\$ /$,



" 6 " 63 to 4 feet, Whips, Mailing Size,



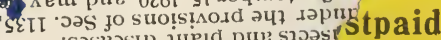
(1)

\section{BARNES NURSERIES \\ 6 ist Year}

Growers of the BEST TREES

College Hill

CINCINNATI, OHIO 